\title{
The American Judiciary Through the Lens of The Federalist Papers
}

By Eric Rayment-Law

\begin{abstract}
The manner in which a Supreme Court justice ought to rule in any given case before him or her is a controversial topic in America, with a number of American lawmakers feeling that each justice should exercise "judicial restraint." Those who feel this way often subscribe to the interpretive strategies of strict construction or originalism, which both cast judges as activists who have a political agenda, imposing it on America while ignoring the Constitution. As a remedy to their grievances, constructionists propose that the constitutional text should be rigorously adhered to while constitutional rights should be narrowly defined. Similarly, originalists propose that the Justices of the American Supreme Court interpret the law according to the intentions of the founding generation. This paper assesses the validity of these interpretive strategies by entertaining the originalist argument (albeit modified) and deferring judgment in this matter to The Federalist number seventy-eight and number ten. Upon analysis of these American founding documents, it is found that the intent of the founding generation to indeed create a judiciary that adheres to the parameters set by the Constitution, but also one that possesses room to incorporate their own judicial philosophies into their legal interpretations as opposed to one that exercises strict judicial restraint.
\end{abstract}

The function of the Supreme Court, as well as the manner in which its justices ought to reach any given ruling, are controversial political topics in America; evident in the seemingly impartial way judicial nominees conduct themselves during their Senate Judiciary Committee hearings. For instance, Justice Roberts declared during his Senate hearing that "[he came] before the committee with no agenda" and likened his judicial philosophy to that of a baseball umpire's in that "umpires don't make the rules; they apply them." 2 This impartial tone can even be observed as recently as Justice Sotomayor's hearing in which she states, "We don't, judges, make law. What we do is, we get a particular set of facts presented to us. We look at what those facts are [...] and then look at the Constitution and see what it says." ${ }^{33}$ This tendency for a judicial nominee to characterize his or her self as being entirely impartial is arguably a direct response to cries within the legislative and executive branches for justices to "exercise judicial restraint so that cases will be decided solely on the law and the principles set forth in the Constitution, not upon an individual justice's philosophical views or preferences." ${ }^{4}$ This "judicial restraint" is often accompanied by the interpretive strategies known as strict construction and originalism. However, by thoroughly analyzing The Federalist number 10 and 78, it is the purpose of this paper to show that the original intent of the founding generation was to create a judiciary that indeed, adheres to the parameters set by the Constitution but also possesses room to incorporate their own judicial philosophies into their legal interpretations as opposed to one that exercises strict judicial restraint.

Before exploring the ways in which these two founding documents support the notion that the judiciary ought to possess ideological flexibility in interpreting the Constitution, they

\footnotetext{
${ }^{1}$ Christopher L. Eisgruber, The Next Justice (Princeton, New Jersey: Princeton University Press, 2007$), 17$.

2 lbid.

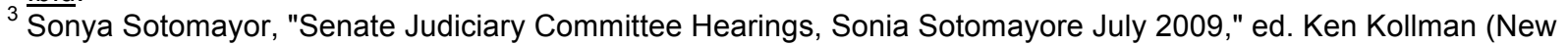
York: W.W. Norton and Company, 2010), 63.

${ }^{4}$ Christopher L. Eisgruber, The Next Justice (Princeton, New Jersey: Princeton University Press, 2007$), 31$.
} 
must be summarized so as to make sense of the overall message they convey. The Federalist number 10 is of the series in regard the Union itself, and from the outset asserts that Union's "tendency to break and control the violence of faction" is an aspect of the Union that must be developed fully. Madison defines a faction as "a number of citizens, whether amounting to a majority or a minority of the whole, who are united and actuated by some common impulse of passion, or of interest, adversed to the rights of other citizens, or to the permanent and aggregate interests of the community." ${ }^{\prime 6} \mathrm{He}$ eventually reaches the conclusion that, by designing the Republic to be a large one, the Union is able to limit the effects of factionalism based on the notion that a faction will be unable to spread its opinions outside of its own state. However before doing this, Madison makes important assertions regarding human nature, implying that factionalism stems from the notion that a man's opinions are objects which his passions are deeply attached to, and that a government cannot quell this notion and must instead protect the "diversity in the faculties of men."7

The Federalist number 78 is very different from The Federalist number 10 in that it deals entirely with the construction as well as the role of the federal judiciary. Hamilton begins by outlining the power of the judiciary in relation to the executive and legislative branches, asserting that it has "neither FORCE nor WILL, but merely judgment;", essentially stating that it does not have the power to table legislation. He instead defines the role of the judiciary as "an intermediate body between the people and the legislature, in order, among other things, to keep the latter within the limits assigned to their authority," ${ }^{19}$ while at the same time making clear that the judiciary is not superior to legislative body, but that the Constitution is superior to both. Overall, Hamilton makes a strong case for the judiciary to be entirely separate from the legislative branch and that its justices be permanently appointed, for both of these conditions give way to a judiciary that is a "bulwark of a limited Constitution against legislative encroachments" $" 10$ that consists of justices with an "independent spirit [...] essential to the faithful performance of so arduous a duty.",11

Now that The Federalist papers under analysis have been summarized, they can be contrasted to the arguments and implementation strategies that drive the judicial restraint concept. The concept as a whole casts the judiciary in a very unflattering light, for it implies that Justices are "activists," or individuals who have a political agenda and "ignore the Constitution along with their judicial roles and recklessly impose their views upon the country." ${ }^{12}$ However this is a misconception that must be rectified, for the judiciary does not actually possess any power to create or table legislation; they are only able to interpret the law. This is fully outlined in The Federalist number 78 where Hamilton states that the judiciary "has no influence over either the sword or the purse; no direction either of the strength or of the wealth of the society; and can take no active resolution whatever. It may truly be said to have neither FORCE nor

\footnotetext{
5 James Madison, "The Federalist" No. 10.

${ }^{6}$ Ibid.

$7 \frac{\text { lbid. }}{\text { lbid. }}$

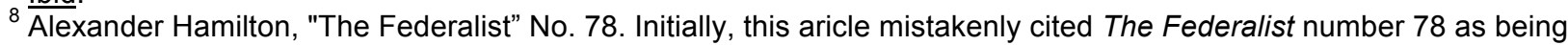
written by Madison. It has since been updated to reflect the correct author.

9 lbid.

${ }_{10}^{10}$ lbid.

$11 \frac{\text { Ibid. }}{\text { Chisto }}$

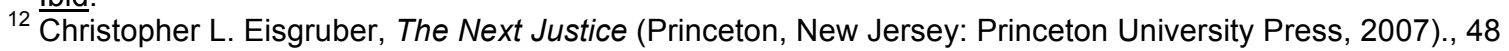


WILL, but merely judgment."13 The judiciary arguably still lacks the qualities of force and will and therefore cannot logically be characterized as a body full of crusading ideologues that proponents of judicial restraint make them out to be. The restrictions on the Court outlined by Hamilton help greatly to ensure it remains a body that adheres to the parameters set by the Constitution.

In response to this analysis, the proponents of judicial restraint will likely argue that a judiciary which adheres to the parameters of the constitution is all they desire, and may refer to a landmark case such as Roe $v$. Wade, and how it effectively legalized abortion, as an example of how the judiciary actively creates laws. In an effort to combat such perceived activism, they promote strategies such as strict construction and originalism. Strict construction is the notion that constitutional text should be rigorously adhered to while constitutional rights should be narrowly defined. ${ }^{14}$ Originalism on the other hand, while it shares in the opinion that the Constitution should be rigorously adhered to, calls for justices to defer their interpretations of the Constitution to the intentions of the founding generation. The logic is that "if someone gives us an unclear instruction, we try to figure out what he or she intended to do. Why not take the same attitude toward the Constitution and its framers?"15

The legitimacy of these strategies can be ironically determined by entertaining the originalist argument (albeit modified) and deferring judgment on this matter to The Federalist number 78. The intention of Hamilton, in regards to the role of the judiciary, undoubtedly supports the notion that the constitutional text should be rigorously adhered to by the justices in their rulings. This is evident in the statement that "a constitution is, in fact, and must be regarded by the judges, as a fundamental law." "However there is certainly no aspect of Hamilton's coverage of the judiciary's structure that calls for the narrow definition of constitutional rights. In fact, such a measure is more akin to what Hamilton refers to as "legislative encroachments" proposed by politicians for which the judiciary is meant to serve as a bulwark against. ${ }^{17}$ Therefore strict construction is not a viable judicial philosophy.

As for originalism, it is arguably useless in helping to pass judgment on individual cases the judiciary takes on. The reason for this is that there is subject matter the founding generation is vague or silent on that the contemporary judiciary must pass judgment on. ${ }^{18}$ A prime example is Roe v. Wade. It deals with the heavily controversial topic of abortion and resulted in abortion becoming a matter of privacy; two areas where the Constitution is completely mute. Therefore it was arguably impossible to defer to the founding generation on this topic. Instead, the justices had to rely on their own judicial and personal philosophies in order to interpret the Constitution in a relevant manner. However, if one analyzes the intent of the founding generation in regard to the function of the judiciary, he or she will see that this is a perfectly valid way of passing judgment in landmark cases. In The Federalist number 78, Hamilton, while expecting of the judiciary to treat the Constitution as "fundamental law," arguably delegates to it an allowance for some personal interpretation. This is most evident where he speaks of the "independent spirit" in

\footnotetext{
${ }^{13}$ Alexander Hamilton, "The Federalist" No. 78.

${ }^{14}$ Christopher L. Eisgruber, The Next Justice (Princeton, New Jersey: Princeton University Press, 2007$)$., 33

15 lbid., 35.

16 Alexander Hamilton, "The Federalist" No. 78.

17 Ibid.

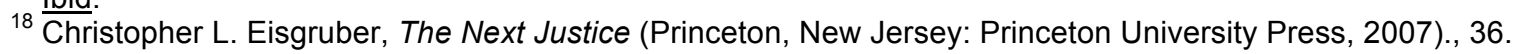


the judiciary "which is essential to the faithful performance of so arduous a duty." This independent spirit Hamilton refers to can be interpreted as the expectation that the justices of the judiciary will at times need to interpret the Constitution using their own philosophies so as to properly fill the role of an "intermediate body between the people and the legislature" 19 that protects against "dangerous innovations in the government, and serious oppressions of the minor party in the community." 20

Armed with the notion that the judiciary possesses an "independent spirit," Roe v. Wade appears very different from the activist light that proponents of judicial restraint may attempt to cast it in. It was a situation where the Constitution was unspecific on the issue, so the Supreme Court ruled that a woman's right to abortion fell under the Fourteenth Amendment's protection of personal liberty on the grounds that a state denial of an abortion could cause a woman various degrees of harm or misfortune. ${ }^{21}$ That being said, the Supreme Court did not rule obtusely, for it placed restrictions on the ruling that only barred the state from intervening in the first trimester. ${ }^{22}$ In this case, while the judiciary undoubtedly reached this ruling through a combination of constitutional and philosophical interpretations, such a combination is a prime example of the independent spirit Hamilton refers to, and with it, the Supreme Court properly protected a minority from a dangerous innovation of the government.

While a Justice's ability to interpret the law partially based on his or her own philosophies draws plenty of justification from The Federalist number 78, it also draws further justification from assertions by James Madison regarding the Union as a whole; which is where The Federalist number 10 becomes relevant. While the primary concern of The Federalist number 10 is to show how a large union limits the effects of factionalism, Madison also takes the opportunity here to make bold statements about human nature; ones that are certainly applicable to the judiciary. He disguises these statements within his quest to do away with factionalism by stating that it can be extinguished by "giving to every citizen the same opinions, the same passions and the same interests." ${ }^{23}$ However he states immediately after that, "as long as the reason of man continues fallible, and he is at liberty to exercise it, different opinions will be formed. As long as the connection subsists between his reason and his self love, his opinions and passions will have reciprocal influences on each other." ${ }^{24}$ This is profound, for Madison considers this notion to be of great importance; so much so that he feels that protecting such faculties is a major requirement of any government. ${ }^{25}$ If this holds true, and since justices are only human and not perfect creatures, one can argue that it is perfectly acceptable for American Supreme Court Justices to interpret the Constitution by relying somewhat on their own passions and ideologies.

It has become evident through the analysis of The Federalist numbers 78 and 10 that, contrary to the beliefs of those who support judicial restraint, the judiciary is not a body with a political will nor is it one that is intended to narrowly define constitutional rights and defer its interpretations in every case to the intent of the founding generation. It is instead a body that

\footnotetext{
${ }^{19}$ Alexander Hamilton, "The Federalist" No. 78.

20 Ibid.

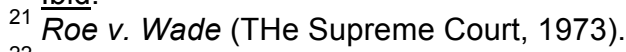

22 lbid.

23 James Madison, "The Federalist" No. 10.

24 Ibid.
} 
adheres to the parameters of the Constitution with room for personal philosophy to influence its constitutional interpretations. This definition finds justification in the notion that the judiciary possesses an independent spirit, that it has a duty to protect minorities from legislative encroachment and that all human beings, regardless of their profession, marry their passions to their opinions; The Justices of the American Supreme Court are no exception. 


\section{Bibliography}

Eisgruber, Christopher L. The Next Justice. Princeton, New Jersey: Princeton University Press, 2007.

Madison, James. "The Federalist No. 10." Library of Congress.

http://thomas.loc.gov/home/histdox/fed_10.html (accessed October 28th, 2010).

Hamilton, Alexander. "The Federalist No. 78." Library of Congress.

http://thomas.loc.gov/home/histdox/fed_78.html (accessed October 28th, 2010).

Roe v. Wade. (The Supreme Court, 1973).

Sotomayor, Sonya. "Senate Judiciary Committee Hearings, Sonia Sotomayore July 2009." Edited by Ken Kollman. New York: W.W. Norton and Company, 2010. 